\title{
OPTIMIZE PRODUCTION BASED ON GOODS USING SUPPLY CHAIN MANAGEMENTS
}

\author{
Murti Retnowo ${ }^{1)}$, Anita Fira Waluyo ${ }^{2)}$ \\ Universitas Teknologi Yogyakarta \\ Jalan Siliwangi, Jl. Ringroad Utara J1. Jombor Lor, Mlati Krajan, Sendangadi, Kec. Mlati, \\ Kabupaten Sleman, Daerah Istimewa Yogyakarta 55285
}

\begin{abstract}
Competitive competition and the arrival of global markets are challenges, these challenges are related to getting products and services that are on time and at a low cost. Organizations or companies begin to realize this and to deal with it is not enough just to increase efficiency in organizations or companies, but the entire supply chain must be competitive. Increasing competition between companies in both local and international markets makes managers determined to focus on how to gain competitive advantage in order to stay in business. At present the achievement of fulfilling customers and getting their trust becomes more and more difficult. This can be obtained through the improvement of products and services, to fulfill both of them, one of which is the application of Supply Chain Management (SCM) and Outsourcing, SCM and Outsourcing methods have been recognized as ways to gain competitive advantage.
\end{abstract}

Keywords : Supply Chain Management (SCM), Optimized Production, Stock of goods, Inventory Control

\section{Pendahuluan}

Kompetisi yang kompetitif dan datangnya pasar global menjadi tantangan tersendiri, tantangan tersebut berkaitan dengan mendapatkan produk dan layanan yang tepat waktu serta biaya yang rendah. Organisasi atau perusahaan mulai menyadari akan hal tersebut dan untuk menghadapinya tidak cukup hanya dengan meningkatkan efisiensi dalam organisasi atau perusahaan tetapi seluruh rantai pasokan harus dibuat kompetitif.

Meningkatnya persaingan antar perusahaan baik di pasar lokal maupun internasional membuat manajer bertekad untuk fokus pada bagaimana cara memperoleh keunggulan kompetitif agar tetap dalam bisnis. Saat ini pencapaian pemenuhan pelanggan dan mendapatkan kepercayaan mereka menjadi hal lebih dan lebih sulit. Hal tersebut dapat diperoleh melalui perbaikan produk dan layanan, untuk memenuhi kedua hal tersebut salah satunya dengan penerapan Supply Chain Manajemen (SCM) dan Outsourcing, metode SCM dan Outsourcing telah diakui sebagai cara untuk mendapatkan keuntungan kompetitif. [2]

Meningkatkan kinerja organisasi dapat diwujudkan antara metode tradisional untuk meningkatkan daya saing, juga dengan kegiatan outsourcing dari global rantai kegiatan yang dilakukan. Tujuan dari outsourcing adalah untuk membuat perusahaan lebih fleksibel dan mudah beradaptasi dengan lingkungan baru kondisi, dengan berfokus pada kegiatan inti, mempercayakan bagian dari tugas, kegiatan atau fungsi untuk perusahaan lain. [3]

Ketidak ketersediaan bahan baku sering manjadi masalah tersendiri dalam sebuah proses produksi, untuk melakukan proses permintaan barang memerlukan waktu yang lama karena memerlukan pencatatan terhadap persediaan data barang yang ada. Pencatatan persediaan barang menjadi lama hal tersebut masih dilakukan secara manual, dengan cara pengguna harus memilah-milah persediaan barang yang berada pada posisi dibawah save stock atau mendekati. save stock. Pemasok adalah sumber yang menyediakan bahan pertama di mana rantai distribusi barang akan dimulai. Saat ini, metode pengambilan keputusan 
tentang pasokan bahan baku bambu untuk UKM Karya Manunggal adalah dengan cara konvensional (intuisi), sehingga seringkali tidak tepat dalam memilih pemasok. Seiring dengan semakin ketatnya tingkat persaingan di bidang furnitur bambu, Karya Manunggal perlu meninjau strategi dalam kompetisi dan untuk mengevaluasi kemampuan pemasok yang merupakan penyedia bahan baku utama [5]. Data pengadaan dan inventaris adalah salah satu hal yang perlu diperhatikan khususnya divisi logistik di perusahaan. Oleh karena itu diperlukan suatu sistem menggunakan metode tertentu yang dapat mendukung manajemen data pengadaan barang dan juga dapat membantu para manajer mengambil keputusan pengendalian stok [9].

SCM sangat efektif untuk digunakan dalam menangani rantai pasokan (perputaran barang) dan mengamankan keunggulan kompetitif serta meningkatkan kinerja organisasi tidak hanya dalam organisasi tetapi antar organisasi di antara rantai pasokan. Konsep dari penelitian dan mengembangkan dimensi SCM seperti strategi kemitraan pemasokan, berbagi dan kualitas informasi serta hubungan antar pemasok [1], selain itu dengan SCM dapat digunakan untuk memaksimal proses produksi dengan memanfaatkan persediaan yang ada atau menghitung berapa kekurangan dan sisa persediaan yang ada setelah dilakukan proses produksi. Kekuatan rantai pasok sangat ditentukan oleh kinerja rantai pasokan. Sedangkan kinerja rantai pasok sangat dipengaruhi oleh strategi manajemen rantai pasok yang diterapkan. Perusahaan melakukan evaluasi terhadap kinerja rantai pasok untuk masukan dalam menyusun strategi manajemen di masa mendatang.

\section{Metode Penelitian}

Pendekatan penelitian yang kita pilih tergantung pada jenis informasi yang kita perlukan, sedangkan metode penelitian yang kita pakai tergantung pada caracara yang kita pilih untuk mengumpulkan informasi tersebut.56 Penetapan strategi penelitian dipilih sesuai dengan informasi yang diperlukan dan rumusan masalah yang ada, Penelitian ini bertujuan untuk mengetahui efisiensi Supply Chain Management (SCM) yang diterapkan pada optimasi produksi berdasarkan ketersediaan bahan baku yang digunakan. Jenis data pada penelitian ini merupakan data kualitatif-kuantitatif dan proses penelitiannya mengambil kesimpulan dari khusus ke umum (induktif).

Adapun langkah-langkah penelitian yang dilakukan antara lain:

a. Pendahuluan Berisi tentang latar belakang dan uraian permasalahan yang perlu diteliti dan dijawab terkait dengan topik penelitian, serta menjelaskan tujuan yang ingin dicapai melalui penelitian.

b. Konsep Supply Chain Management digunakan dengan Melakukan kajian pendekatan penerapan construction supply chain management dalam pengadaan material di perusahaan dan proyek konstruksi yang akan diteliti berdasarkan landasan teori yang mendukung penelitian ini

c. Melaksanakan penelitian dengan metode wawancara atau interview terhadap responden yang akan diteliti dan mengumpulkan sebanyak mungkin data yang diperoleh dari studi kasus yang dilakukan dan proyek konstruksi yang diteliti, yakni menyangkut kemungkinan dilakukannya penerapan construction supply chain management, keuntungan dan kerugian yang akan diperoleh, kendala dan komitmen penerapan SCM, serta faktor-faktor kunci yang menjadi penentu kesuksesan penerapan SCM. Identifikasi masalah, hal ini membahas mengenai perkiraan permasalahan dan kondisi yang terjadi pada proses produksi.

d. Mengumpulkan hasil wawancara dan studi literatur serta melakukan pembahasan atau analisa data untuk mengkaji sejauhmana posisi tahapan evolusi dalam rencana melaksanakan penerapan proses construction supply chain management. 
e. Melakukan proses penerapan SCM berdasarkan hasil dari wawancara dan pengumpulan studi pustaka.

f. Melakukan Uji coba terhadapa hasil program jika belum sesuai akan dilakukan analisis kembali melibatkan narasumber, jika sudah sesuai maka akan dilakukan proses uji coba untuk mendapatkan saran dari kekurangan atau hal-hal yang harus ditambahkan.

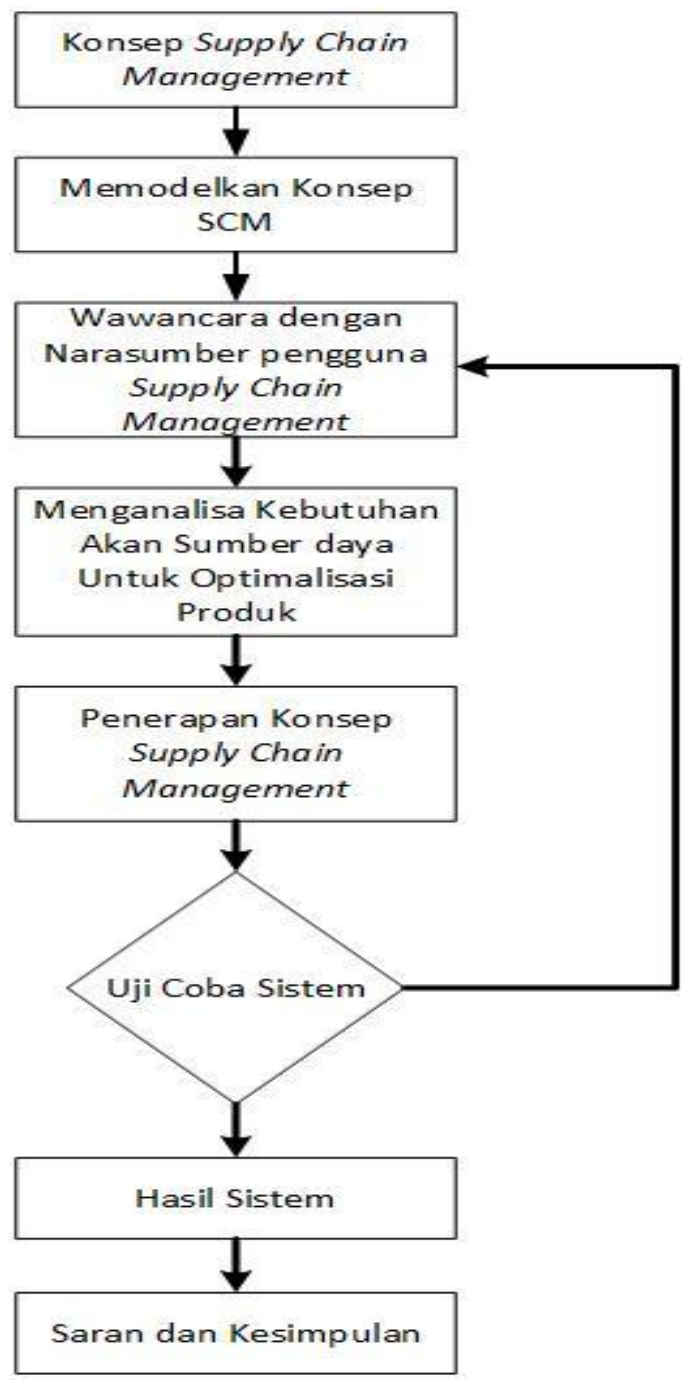

Gambar 1 Metode Penelitian

\subsection{Supply Chain Management Model}

Supply Chain planning memungkinkan produsen untuk melakukan sinkronisasi data produksi dengan data pasokan diseluruh jaringan perusahaan dengan seluruh permintaan yang ada dalam perusahaan tersebut. SCM memungkinkan produsen untuk mengumpulkan semua permintaan yang ada dan melakukan perencanaan secara terpusat untuk menghitung kapasitas produksi dan pasokan yang diperlukan untuk memenuhi permintaan yang ada. Modul SCM melakukan konsolidasi informasi penjualan, produksi, inventaris, dan pembelian untuk membantu perusahaan menjadi lebih berorientasi pada permintaan dan melakukan Made By Order (produksi barang berdasarkan permintaan).

Dalam pasar berorientasi permintaan saat ini, untuk mengoptimalkan dan mengintegrasikan penjualan dan logistik dan kemudian memasukkan data ke dalam jadwal 
produksi tepat waktu sangat penting. Supply Chain Management memberikan manfaat besar bagi produsen yang memungkinkan mereka untuk:

a. Tingkatkan respons terhadap perubahan pasar.

b. Tingkatkan visibilitas ke dalam permintaan agregat, produksi dan pasokan di seluruh perusahaan.

c. Kurangi tingkat inventaris.

d. Meningkatkan layanan pelanggan dan kinerja pengiriman tepat waktu.

e. Mengoptimalkan pasokan untuk memenuhi permintaan secara menguntungkan.

f. Persediaan, distribusi, dan biaya transportasi lebih rendah.

g. Meningkatkan akurasi perkiraan permintaan dengan waktu siklus perencanaan terkompresi

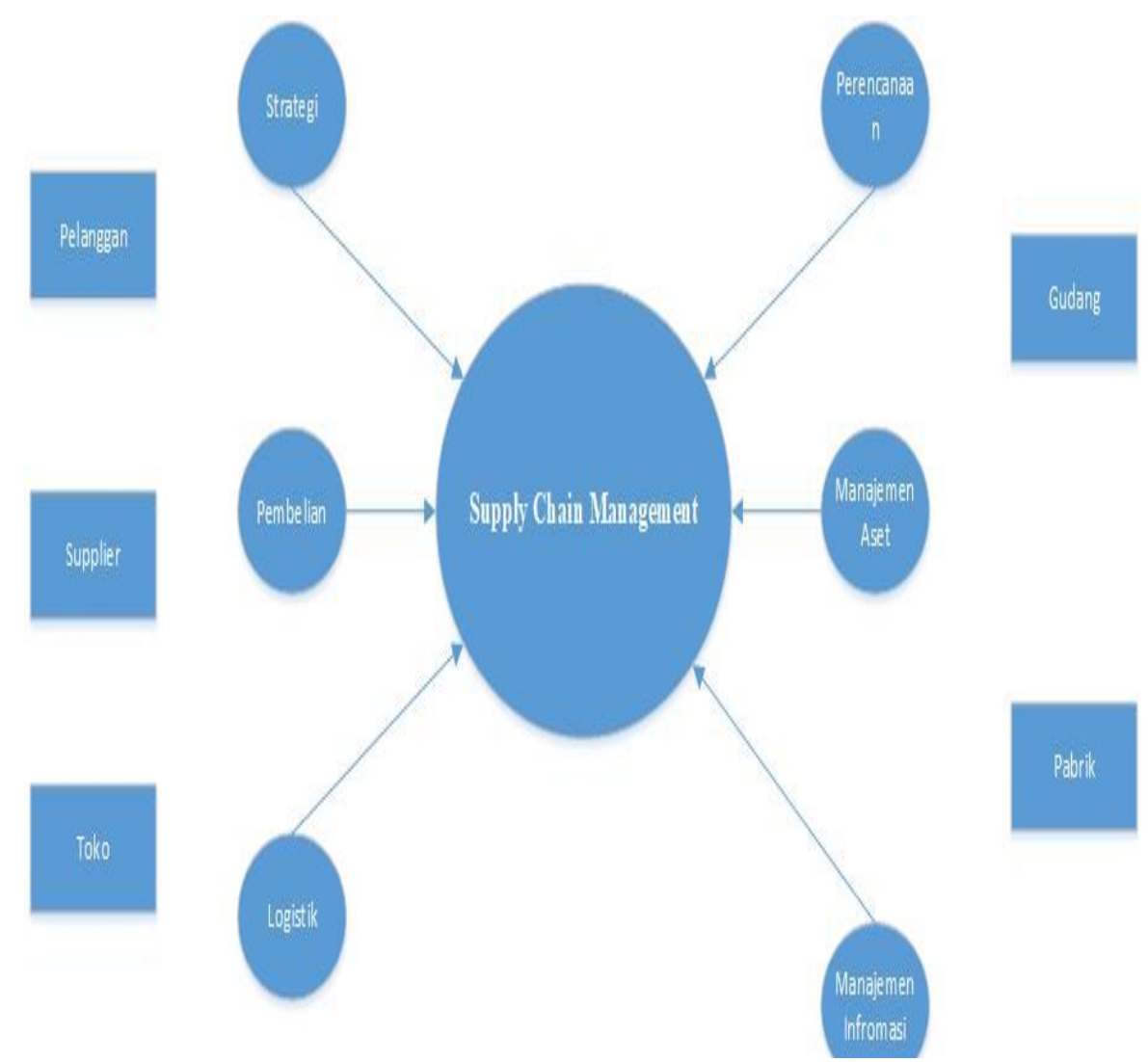

Gambar 2. Prinsip Kerja SCM

Modul Supply Chain Management (SCM): [4]

a. Manajemen Pre Sales (Pra Penjualan)

b. Otomasi Salesmen (tenaga penjualan)

c. Customers Relationship Management (CRM)

d. Penjualan, faktur dan pengiriman

e. Manajemen pembelian

f. Manajemen Stok terpusat

g. Konektivitas antar bagian (Client Server Model Programming /Cloud Hosting)

\subsection{Bisnis Proses}

Supply Chain Management memiliki 3 Komponen, yang di antaranya adalah Upstream Supply Chain Management yaitu sebuah proses dimana perusahaan mendapatkan supplier dari pihak luar untuk mendapatkan bahan baku. Kemudian komponen yang kedua adalah Internal Supply Chain Management yaitu sebuah proses dimana terjadinya 
perubahan dari bahan baku menjadi sebuah produk jadi. Komponen terakhir SCM adalah Downstream Supply Chain Managament yaitu sebuah proses dimana pendistribusian barang oleh perusahaan ke customer yang dimana biasanya dilakukan oleh eksternal distributor.

Proses yang terlibat dalam SCM adalah

\section{a. Customer}

Pada sebagian perusahaan, customer merupakan mata rantai pertama yang memberi order. Customer memutuskan untuk membeli produk yang ditawarkan oleh perusahaan yang bersangkutan dengan menghubungi departemen sales perusahaan tersebut. Informasi penting yang terdapat dalam pesanan tersebut diantaranya seperti tanggal pengiriman produk dan jumlah yang diinginkan untuk produk yang dipesan.

b. Planning

Setelah custumer membuat pesanan yang diinginkan, Planning department akan mempersiapkan perencanaan produksi untuk memproduksi produk yang dibutuhkan oleh customer. Pada tahap ini, Planning department juga menyadari akan adanya kebutuhan terhadap bahan baku dan bahan - bahan pendukungnya.

c. Purchasing

Setelah menerima perencanaan produksi, dalam hal ini adalah kebutuhan terhadap bahan mentah dan bahan-bahan pendukungnya, Departemen pembelian atau Purchasing Departement akan melakukan pemasukan bahan mentah dan bahan pendukungnya serta menetapkan tanggal penerimaan dan jumlah yang dibutuhkan.

d. Inventory

Bahan mentah dan bahan pendukung yang telah diterima oleh pabrik akan diperiksa kualitas dan ketepatan jumlahnya kemudian disimpan di dalam Gudang untuk kebutuhan produksi.

e. Production

Bagian produksi akan menggunakan bahan mentah dan bahan pendukung yang dipasok oleh supplier tersebut untuk melakukan proses produksi hingga menghasilkan barang jadi yang dibutuhkan oleh customer. Barang jadi yang telah diproduksi ini kemudian dimasukan ke gudang dan siap untuk dikirim ke customer sesuai dengan jadwal yang di tentukan.

\section{Implementasi}

Proses optimasi dimulai dengan adanya sebuah permintaan atau akan melakukan proses produksi, permintaan dapat berdasarkan permintaan pelanggan atau dapat pula berupa proses produksi secara rutin. Optimasi dapat dilakukan ketika sudah mengetahui produk apa yang akan dibuat dan berapa jumlah proses produksi yang akan dihasilakn serta melihat stok bahan baku yang ada digudang.

Perhitungan optimasi dilakukan dengan mencari stok barang yang ada dikurangi sisa hasil bagi dari proses yang ada dengan rumus:

dimana:

$$
\mathrm{O}=(\mathrm{a}-(\mathrm{a} \bmod \mathrm{n})) / \mathrm{n}
$$

n: jumlah bahan baku yang digunakan dalam 1 proses produksi

a: jumlah stok bahan baku

sebagai contoh untuk menghasilkan produk B memerlukan banyak bahan baku diantaranya bahan baku A mempunyai stok sebesar 35 buah untuk menghasilkan sebuah produk memerlukan bahan baku A sebanyak 9 buah maka dilakukan perhitungan sebagai berikut: mencari sisa hasil bagi

$$
\begin{aligned}
& \mathrm{s}=35 \bmod 9 \\
& \mathrm{~s}=8
\end{aligned}
$$


untuk menghitung optimasi

$$
\begin{aligned}
& \mathrm{O}=(35-\mathrm{s}) / 9 \\
& \mathrm{O}=(35-8) / 9 \\
& \mathrm{O}=3
\end{aligned}
$$

Sehingga nilai produk optimal yang dihasilkan berdasarkan optimal bahan baku A adalah 3 produk yang selanjutnya akan dibandingkan dengan bahan-bahan baku lainnya yang digunakana untuk menghasilkan produk tersebut sehingga menghasilkan nilai paling optimal untuk menghasilkan suatu produk. Alur proses optimasi produksi dapat dilihat pada gambar 2 dibawah ini.

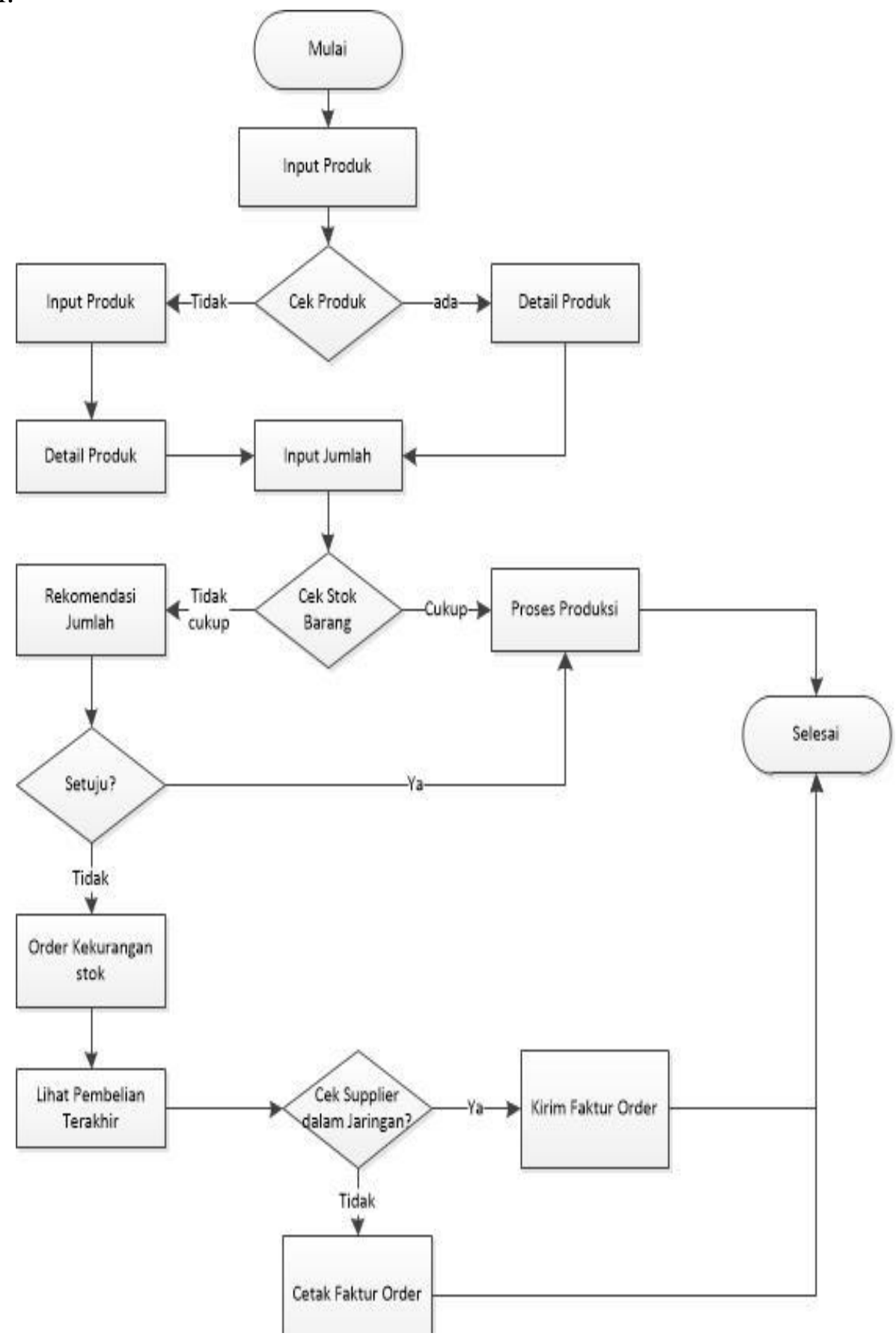

Gambar 3 Alur Program

Proses optimasi dengan supply chain management dimulai dengan menentukan produk apa yang akan dibuat dan berapa jumlah yang akan dihasilkan sehingga dapat 
dikumpulkan bahan baku apa saja yang akan digunakan untuk membuat produk tersebut serta menghitung jumlah ketersediaan bahan baku yang digunakan untuk membuat produk tersebut berserta banyaknya bahan baku yang digunakan untuk menghasilkan produk berserta jumahnya, kemudian setelah itu dilakukan proses Pembandingan pada masing-masing bahan baku yang didasarkan pada jumlah bahan baku yang dibutuhkan dengan ketersediaan bahan baku yang ada pada Gudang.

Proses perbandingan kebutuhan bahan baku dengan ketersediaan bahan baku digunakan untuk melakukan optimasi jumlah produk yang akan dihasilkan. Optimasi dilakukan dengan cara membandingkan jumlah produk yang dapat dihasilkan dari masingmasing bahan baku, sehingga didapat jumlah produk optimal yang akan dihasilkan untuk dilakukan proses produksi atau memberikan informasi optimasi produksi berdasarkan ketersediaan bahan baku yang ada kepada pengguna bahwa optimal produk yang dihasilkan sudah didapatkan, selanjutnya tergantung dari pengguna apakah akan dilakukan proses produksi sesuai dengan jumlah optimal atau akan dikurangi atau tetap sesuai dengan pesanan, jika sesuai dengan pesanan maka ketika nilai optimal berada dibawah nilai order maka akan dilakukan pemesan barang kepada supplier berdasarkan pembelian terakhir dan jumlah yang dibutuhkan.

\section{Kesimpulan}

Hasil penerapan Supply Chain Management pada penelitian ini adalah:

a. Program mampu memberikan informasi optimasi produk yang akan dihasilkan kepada pengguna berdasarkan pada stok barang yang ada yang sesuai dengan kebutuhan bahan baku produksi.

b. Program mampu memberikan informasi kepada pengguna mengenai stok barang yang ada dan pembelian barang terakhir.

c. Untuk penerapan order secara otomatis semua supplier harus terhubung dalam 1 jaringan.

\section{Ucapan Terimakasih}

Dengan selesainya Jurnal ini kami selaku penulis mengucapkan terimakasih kepada :

1. Dr. Bambang Moertono Setiawan, M.M., C.A., Akt. Selaku Rektor Universitas Teknologi Yogyakarta berserta jajarannya.

2. Sutarman M.Kom. Ph.D. Selaku Dekan Fakultas Teknologi Informasi berseta jajarannya

3. Bapak/Ibu Dosen Prodi Manajemen Infromatika yang sudah membantu dalam penulisan

4. Ifah Rofiqoh, S.E., M.Si., Ak., C.A. Selaku Ketua Lembanga Penelitian dan Pengabdian Kepada Masyarakaat (LPPM UTY)

\section{Daftar Pustaka}

[1] Hila, C. M., \& Dumitraşcu, O. (2014, November). Outsourcing Within A Supply Chain Management Framework. In Proceedings of the 8th International Management Conference "Management Challenges for Sustainable Development (pp. 328-336).

[2] Raja, M. \& Kherun, N., 2006 Relationship between Supply Chain Management and Outsourcing, Universiti Teknologi Malayzia

[3] Li, S., Ragu-Nathan, B., Ragu-Nathan, T. S., \& Rao, S. S. (2006). The impact of supply chain management practices on competitive advantage and organizational performance. Omega, 34(2), 107-124.

[4] Module Supply Chain Management https://www.acgil.com/products/scm-modules.htm diakses pada tanggal 15 Juli 2019 
[5] Hanan, Z., Nurdin, R., \& Astuti, M. (2018, November). The Supplier Evaluation in Bamboo Karya Manunggal Furniture Industry Using Analytic Network Process (ANP) Method. In Conference SENATIK STT Adisutjipto Yogyakarta (Vol. 4, pp. 413-419).

[6] Retnowati, N. D. (2018, November). Project Optimization of WEB-Based 3d Animation Bus Route Trans Jogja Using CPM. In Conference SENATIK STT Adisutjipto Yogyakarta (Vol. 4, pp. 295-301).

[7] Rengganis, E. (2015). Perbandingan Optimasi Re-Layout Penempatan Fasilitas Produksi Dengan Menggunakan Craft Guna Meminimalkan Biaya Material Handling. Jurnal Angkasa, 7(1), 181-198.

[8] Indrianingsih, Y. (2018, November). Decision Support System to Determine the Number of Production Tofu using the Fuzzy Sugeno Method (Case Study: Home Industries Tofu in Seyegan District). In Conference SENATIK STT Adisutjipto Yogyakarta (Vol. 4, pp. 191-200).

[9] Amanu, G. S., \& Indrianingsih, Y. (2015). Pengembangan Sistem Pendukung Keputusan Pengadaan dan Persediaan Barang dengan Metode Perpetual Inventory Method dan Economic Order Quantity (Studi Kasus: Divisi Logistik Rumah Sakit Krakatau Medika Cilegon). Compiler, 4(1).

[10] Prasetio, E., \& Irawaty, M. (2014). Sistem Pendukung Keputusan untuk Memprediksi Jumlah Pakaian dengan Menggunakan Metode Weight Moving Average dan Exponential Smoothing (Studi Kasus di Toko Rookieinside Yogyakarta). Compiler, $3(2)$. 